\title{
SOURCE-SINK MANIPULATION AND POPULATION DENSITY EFFECTS ON FODDER AND GRAIN YIELD OF HYBRID MAIZE
}

\author{
Shah-Al-Emran, K. M. S. Haque, Q. A. Khaliq and M. Y. Miah ${ }^{1}$ \\ Department of Agronomy, ${ }^{1}$ Department of Soil Science, Bangabandhu Sheikh Mujibur Rahman Agricultural University, \\ Gazipur- 1706, Bangladesh \\ Corresponding author: s.emran@cgiar.com
}

Key words: Source-sink, fodder, hybrid maize and BCR

\begin{abstract}
An experiment was carried out in the field laboratory at the Bangabandhu Sheikh Mujibur Rahman Agricultural University, Gazipur, Bangladesh, during rabi season of 2009-2010. Planting material was maize var. BARI hybrid maize 7.Three levels of population density (66667, 83333 and 111111 plants ha ${ }^{-1}$ ) and four source-sink manipulation, viz. removed all leaf blades below the lower most cob, removed tassel and all leaf blades below the lower most cob, removed all leaf blades except those adjacent to cob and no clipping, were imposed at silking stage. During crop growth, removal of all leaf blades below the cob showed less adverse effect on grain yield and yield parameters and the leaves so removed can be used as green fodder. Removal of tassel and all leaf blades except those adjacent to cob showed adverse effect on grain yield and yield parameters. Complete defoliation severely reduced grains on cob. The highest gross return and benefit cost ratio (BCR) was obtained from the treatment having 1,11,111 plants ha ${ }^{-1}$ with no clipping while the lowest from the treatment with removal of all leaf blades excluding those adjacent to cob in 66667 plants ha ${ }^{-1}$. In case of dual purpose, 1,11,111 plants ha ${ }^{-1}$ with removal of tassel and all leaf blades below the lower most cob gave the highest gross return but 66667 plants $\mathrm{ha}^{-1}$ with removal of all leaf blades below the lower most cob gave the highest BCR (1.78)
\end{abstract}

\section{Introduction}

Maize (Zea mays) is a major crop used as food, feed, fuel and a source of carbohydrate, oil, protein and fiber. Dry-matter production and grain yield are limited by the source-sink affiliation of crop assimilates and the end nutrient availability in the grain is expected to be constrained by the sink capacity as well as by the contribution of source (Zhang et al., 2012).Various ways of leaf clipping have influences on dry matter accumulation and grain yield. It was reported that tassel clipping two days after silking, generally increases the grain yield at 6.7 percent more than the control due to increased grain weight (Wang, 1996). Leaf clipping of upper three leaves at 2 and 16days after tasseling, decreases grain yield by 24 and 9 percent, respectively (Wang, 1996). When leaf clipping done at the primary stage of grain development, the grain yield decrease would arise due to increased grain number (Wang, 1996). Leaf clipping at early season significantly reduces both the stem length and leaf area; however, it did not have any effect on leaf emergence. Also, leaf clipping at early season decreased soluble grain carbohydrate in order to devote the carbohydrates for vegetative growth and reduce sucrose sources (Prioul and Dugue, 1992). It was noticed that when the defoliation was severe and its time was closer to silking stage, forage yield and soluble sugars decreased greatly (Burton, 2004).

The effect of leaf defoliation on canopy photosynthesis and changing the sink and source carbohydrates showed that soluble sugars in plants with leaf clipped (control, above ear leaf clipping, below ear leaf clipping and full leaf clipping at flowering stage) was different (Egile, 2000). It was observed that full leaf clipping treatment made the most decrement of canopy photosynthesis and changing the sink and source carbohydrates and the percentage of soluble sugar in different parts of plant such as grains (Egile, 2000). The grains of plants which had limitation on their sinks were not able to use possible carbohydrates (Burton, 2004). Cultivar and leaf clipping treatments had significant effects on grain yield, 
Emran et al.

globulin, glutenin, prolamine, albumin and soluble carbohydrates. The grain yield is mostly observed in above ear leaf clipping treatment which is followed by ear leaf clipping and below ear leaf defoliation.

Grain yield is a function of dry mass production and harvest index. Yield is mostly related with its dry matter production ability. For a genotype, generally the higher the dry matter accumulation, the greater is the yield under favorable condition. However, there is little information on the interaction between leaf clipping and planting density to grain and fodder yield of maize. This study was undertaken to elucidate the effect of different levels of leaf clipping and population density on grain yield and yield attributing characters and green fodder yield of maize.

\section{Materials and Methods}

A field experiment was conducted in research field of Bangabandhu Sheikh Mujibur Rahman Agricultural University (Latitude: $24^{\circ} 09^{\prime}$ N., Longitude: $90^{\circ} 25^{\prime}$ E., and 8.4 meters above sea level) in winter 2009-10, to study the relations between source-sink manipulation and population density in corn plants. The soil of the experimental site was silty clay loam (clay of $35.6 \%$, sand of $17.2 \%$, and silt of $47.2 \%$ ) with $\mathrm{pH} 5.6$, and organic carbon of $0.65 \%$. The experiment was conducted in a randomized complete block design with three replications. A total of three population densities viz. 66,667 (75 cm x $20 \mathrm{~cm}), 83,333(60 \mathrm{~cm} \times 20 \mathrm{~cm})$ and 1,11111 (60 cm x $15 \mathrm{~cm})$ plants ha ${ }^{-1}$ and four leaf \& tassel clippings were used in this experiment. Among the clipping treatments, no clipping was treated as control $\left(\mathrm{C}_{1}\right)$, with other three levels, i.e. removal of all leaf blades below the lowermost $\operatorname{cob}\left(\mathrm{C}_{2}\right)$, removal of tassel and all leaf blades below the lowermost cob $\left(\mathrm{C}_{3}\right)$ and removal of all leaf blades except those adjacent to cob $\left(\mathrm{C}_{4}\right)$.

The seeds of BARI Hybrid maize-7 were planted by maintaining different population density, as mentioned above, and clipping treatments were applied during silking stage of plant growth. The sourcesink manipulation treatments were imposed by removing the designated source organs with scissors after silking stage. Leaf area was measured, at 7 days intervals throughout the growth period by an automatic leaf area meter immediately after leaf clipping. Three plants were randomly collected from each unit plot and all the green leaves were taken for measuring leaf area by a leaf area meter (Model AMM-8, Hayashi Dehnko Co. Ltd., Tokyo, Japan). Leaf area index was calculated by using the following formula

$$
\mathrm{LAI}=\frac{\text { Sum of the leaf area of all leaves }}{\text { Ground area from where the leaveshave been collected }}
$$

The data on yields and yield contributing characters of maize varieties and soil parameters were statistically analyzed by "MSTATC" software to examine the significant variation of the results due to different treatments. The treatment means were compared by LSD at $5 \%$ level of significance.

\section{Results and Discussion}

\section{Cob length}

Cob length varied significantly among the plant population grown at different densities and clipping levels (Table 1). Length of cob decreased significantly with the increasing level of population density. The plants grown at the lower density (66667 plants ha ${ }^{-1}$ ) produced the longest cob $(154.7 \mathrm{~mm})$ where leaf blades were removed below the lower most cobs. However, no significant reduction was recorded in cob length in other clipping treatment in same density. In contrast, the lowest cob length $(119.3 \mathrm{~mm})$ was 
Sourch-Sink Manipulation and Population Density of Hybrid Maize

found in plants grown at 1,11,111 plants $\mathrm{ha}^{-1}$ and removed the tassel and all leaf blades below the lowermost cob. Similar finding was reported by Osorio (1976), Loesch et al. (1976) and Rathore et al. (1976).

\section{Cob diameter}

The data pertaining to cob diameter as influenced by plant density, levels of defoliation and their interactions are presented in Table 1. Significant differences in cob diameter were noticed due to plant density and levels of defoliation. Maximum cob diameter $(46.36 \mathrm{~mm})$ was recorded in treatments where all leaf blades below the lowermost cob were removed with 66,667 plants ha $^{-1}$. However, minimum cob diameter $(39.04 \mathrm{~mm})$ was recorded in 1,11,111 plants $\mathrm{ha}^{-1}$ where tassel and all leaf blades below the lowermost cob were removed.

\section{Number of grains per cob}

Significant variations were observed in number of grains per cob in all plant densities and clipping levels (Table 1). However, increasing level of clipping decreased the number of grains per cob. A gradual reduction in number of grains per cob with increasing the level of clipping was observed. Among the treatments, the highest number of grains per cob (406) was recorded at the density of 66,667 plants ha ${ }^{-1}$ with no clipping $\left(C_{1}\right)$. However, no significant difference in grain numbers was found in other clipping treatments except 66667 plants $\mathrm{ha}^{-1}$. On the other hand, the lowest grains per cob were found in 1,11,111 plants ha ${ }^{-1}$ with removal of all leaf blades except those adjacent to cob. Statistically similar result was also found in removal of tassel and all leaf blades below the lower most cobs. In 83,333 plants ha ${ }^{-1}$, clipping treatments gave statistically similar result except removal of all leaf blades except those adjacent to cob which gave lower grains per cob than other clipping treatments. Similar finding was reported by Rathore et al. (1976).

\section{0-grain weight}

100 grain weight of maize was subjective to different density levels (Table 1). However, increasing level of clipping decreased the 100-grain weight, even, within same density level. A gradual reduction in 100grain weight per treatment with the increasing level of clipping was also observed among the plant densities. It was recorded that tested hybrid maize produced the highest 100-grain weight (28.79 g) in 83333 plants ha ${ }^{-1}$ with no clipping $\left(\mathrm{D}_{2} \mathrm{C}_{1}\right)$. However, the lowest 100 -grain weight $(24.49 \mathrm{~g})$ was found in same density with removal of all leaf blades except those adjacent to cob.

\section{Grain yield}

Grain yield is the product of number of plant $\mathrm{ha}^{-1}$, $\mathrm{cobs}_{\mathrm{plant}}{ }^{-1}$, grains $\mathrm{cob}^{-1}$ and individual grain weight. Clipping treatment, at all density levels, there was a large impact on grain yield of maize (Table 1) revealed that the grain yield significantly increased with the increasing level of density and decreased due to clipping. Grain yield increased up to $7.9 \mathrm{t} \mathrm{ha}^{-1}$ in $1,11,111$ plants ha ${ }^{-1}$ with no clipping $\left(\mathrm{D}_{3} \mathrm{C}_{1}\right)$ and thereafter decreased with the interaction in density and clipping levels. Except 1,11,111 plants ha ${ }^{-1}$ with no clipping and those three, all treatment was statistically similar. Only 83333 plants ha ${ }^{-1}$ with removal of all leaf blades except those adjacent to cob, 1,11,111 plants ha $^{-1}$ with removal of all leaf blades except those adjacent to cob and 66667 plants ha ${ }^{-1}$ with removal of all leaf blades except those adjacent to cob produced less than $5.21 \mathrm{t} \mathrm{ha}^{-1}$ grain where all other treatments produced more than $5.9 \mathrm{t} \mathrm{ha}^{-1}$ grain yield with a central tendency of $6.5 \mathrm{t} \mathrm{ha}^{-1}$ grain yield. Furthermore, the yield increment was mainly owing to improvement in yield attributing characters at higher leaf present. In 1,111,11 plants ha ${ }^{-1}$ with no clipping, LAI was significantly highest and the number of plant as well as cob ha ${ }^{-1}$ showed same result. Increased grain yield under increasing level of leaf present might have increased in photosynthetic capacity due to increase in photosynthetic leaf surface, chlorophyll content, leaf longevity and partitioning of more accumulated dry mass from source to sink, favorable growth and nutrient uptake resulted hence produced higher grain yield. Plants grew healthy and produced long size of cobs with bold 
Emran et al.

and heavy grains in 66667 plants ha ${ }^{-1}$ density. The results of present study can be favorably compared with those of Hassen (2003), Zewdu (2003), Li-xiangjun et al. (2005) and Chaudhary et al. (2005). Narayanaswamy et al. (1994) and Simeonov and Tsankova (1990) also reported similar result. In contrast, Vivas et al. (1988) reported that plant density was not a critical factor in determining maize yield.

Table 1. Yield attributes of three population densities grown under four different clipping levels

\begin{tabular}{c|c|c|c|c|c|c}
\hline $\begin{array}{c}\text { Treatment } \\
\text { combination }\end{array}$ & $\begin{array}{c}\text { Cob length } \\
(\mathrm{mm})\end{array}$ & $\begin{array}{c}\text { Cob diameter } \\
(\mathrm{mm})\end{array}$ & $\begin{array}{c}\text { Grains } \\
\text { cob }^{-1} \\
\left(\mathrm{no.}^{2}\right.\end{array}$ & $\begin{array}{c}100 \text {-grain } \\
\text { weight } \\
(\mathrm{g})\end{array}$ & $\begin{array}{c}\text { Grain yield } \\
\left(\mathrm{t} \mathrm{ha}^{-1}\right)\end{array}$ & $\begin{array}{c}\text { Harvest } \\
\text { index } \\
(\%)\end{array}$ \\
\hline $\mathrm{D}_{1} \mathrm{C}_{1}$ & 152.5 & 45.91 & 406.0 & 28.56 & 6.572 & 45.75 \\
$\mathrm{D}_{1} \mathrm{C}_{2}$ & 154.7 & 46.36 & 401.2 & 27.90 & 6.232 & 54.18 \\
$\mathrm{D}_{1} \mathrm{C}_{3}$ & 148.9 & 45.89 & 371.5 & 27.70 & 5.927 & 51.50 \\
$\mathrm{D}_{1} \mathrm{C}_{4}$ & 141.1 & 43.67 & 304.3 & 25.46 & 4.238 & 39.66 \\
$\mathrm{D}_{2} \mathrm{C}_{1}$ & 141.6 & 43.99 & 331.2 & 28.79 & 6.486 & 44.17 \\
$\mathrm{D}_{2} \mathrm{C}_{2}$ & 135.1 & 42.98 & 302.9 & 27.48 & 6.149 & 50.79 \\
$\mathrm{D}_{2} \mathrm{C}_{3}$ & 134.8 & 44.48 & 308.5 & 28.05 & 6.323 & 59.14 \\
$\mathrm{D}_{2} \mathrm{C}_{4}$ & 132.1 & 42.58 & 280.3 & 24.49 & 4.695 & 44.73 \\
$\mathrm{D}_{3} \mathrm{C}_{1}$ & 131.3 & 43.30 & 314.3 & 28.41 & 7.906 & 48.06 \\
$\mathrm{D}_{3} \mathrm{C}_{2}$ & 123.3 & 40.25 & 272.1 & 27.13 & 6.478 & 51.06 \\
$\mathrm{D}_{3} \mathrm{C}_{3}$ & 119.3 & 39.04 & 213.9 & 25.90 & 6.536 & 52.03 \\
$\mathrm{D}_{3} \mathrm{C}_{4}$ & 120.9 & 39.66 & 195.6 & 26.45 & 5.206 & 48.97 \\
\hline $\mathrm{LSD}_{(0.05)}$ & 11.13 & 2.314 & 45.37 & 1.604 & 0.9473 & 8.288 \\
$\mathrm{CV}_{(\%)}$ & 4.82 & 3.16 & 8.69 & 3.48 & 9.23 & 9.95 \\
\hline
\end{tabular}

$\mathrm{D}_{1}=(75 \mathrm{~cm} \times 20 \mathrm{~cm}), 66667$ plants $\mathrm{ha}^{-1}$

$\mathrm{D}_{2}=(60 \mathrm{~cm} \times 20 \mathrm{~cm}), 83333$ plants ha ${ }^{-1}$

$\mathrm{D}_{3}=(60 \mathrm{~cm} \times 15 \mathrm{~cm}), 111111$ plants ha ${ }^{-1}$

$\mathrm{C}_{4}=$ Removal of all leaf blades except those adjacent to cob

The price of maize grain and fodder: $\mathrm{Tk} . \mathrm{Kg}^{-1} 12.50$ and 2.5

\section{Harvest index}

The ratio of economic yield to biological yield is termed as harvest index. The highest harvest index (59.14\%) was found in 83,333 plants ha $^{-1}$ with removal of tassel and all leaf blades below the lower most cob treatment (Table 2). The lowest HI (39.66\%) was recorded in 66667 plants ha $^{-1}$ with removal of all leaf blades except those adjacent to cob treatment with no clipping, 83333 plants ha ${ }^{-1}$.

\section{Correlation analysis}

\section{Relationship between plant density and dependent variables}

Correlation analysis evinces that cob length $(r=-0.82)$, cob diameter $(r=-0.745)$, number of grain per $\operatorname{cob}(r=-0.74)$, grain weight per cob $(r=-0.67)$, total dry matter content $(r=-0.69)$, light transmission rate before clipping $(r=-0.685)$ had negative and significant $(1 \%)$ relationship with crop density but none of the parameters exhibits significant positive relationship with crop density (Table 2). This may be due to the struggle created by plant density. Closer planting creates competition for nutrients and all other growth factors. Grain yield showed affirmative but insignificant relationship with plant density might be that the number of cob increases with number of plant. The finding is consistent with the findings of Osorio (1976), Rathore et al. (1976), Hsu and Huang (1984) and Loesch et al. (1976).

\section{Relationship between leaf clipping and dependent variables}


Sourch-Sink Manipulation and Population Density of Hybrid Maize

The computed Pearson's product moment correlation co-efficient at 5\% level of probability implies that number of grain per cob $(r=-0.48)$, grain weight per cob $(r=-0.55), 100$-grain weight $(r=-0.71)$, grain yield $(r=-0.71)$, total dry matter production $(r=-0.67)$ and leaf area index $(r=-0.91)$ maintained negative significant relationship with leaf clipping (Table 2). The results confirms with the results of previous findings of Zelitch (1982), Chaudhary et al. (2005) and Hassen (2003). The reason behind such type of relationship might be due to the fact that leaf clipping increases light transmission ratio and total photosynthetic activity may be reduced. On the other hand light transmission rate after clipping $(r=0.8)$ maintained positive significant relationship with leaf clipping.

Table 2. Relationship between plant components with different treatment variables as influenced by leaf clipping and plant density

\begin{tabular}{|c|c|c|c|c|c|c|c|c|c|c|}
\hline & $\begin{array}{l}\text { Cob } \\
\text { length }\end{array}$ & $\begin{array}{c}\text { Cob } \\
\text { diameter }\end{array}$ & $\begin{array}{l}\text { No. of grain } \\
\text { cob }^{-1}\end{array}$ & $\begin{array}{l}\text { Grain } \\
\text { wt. } \\
\text { cob }^{-1}\end{array}$ & $\begin{array}{l}100 \\
\text { grain } \\
\text { wt. }\end{array}$ & $\begin{array}{l}\text { Grain } \\
\text { yield }\end{array}$ & $\begin{array}{c}\text { Fodder } \\
\text { yield }\end{array}$ & $\begin{array}{c}\text { Total } \\
\text { dry } \\
\text { matter }\end{array}$ & $\begin{array}{l}\text { Leaf } \\
\text { area } \\
\text { index }\end{array}$ & $\begin{array}{c}\text { Light } \\
\text { transmission } \\
\text { ratio }\end{array}$ \\
\hline density & $-.823^{* * 4}$ & $-.745^{* *}$ & $-.742^{* * *}$ & $-.674^{* *}$ & -.116 & .300 & .243 & $-.686^{* *}$ & .161 & -.075 \\
\hline clipping & -.305 & -.306 & $-.482^{* *}$ & $-.549^{* *}$ & $-.710^{* *}$ & $-.713^{* *}$ & $.905^{* *}$ & $-.672^{* *}$ & $-.905^{* *}$ & $.805^{* *}$ \\
\hline Cob length & 1 & $.901^{* *}$ & $.897^{* *}$ & $.883^{* *}$ & $.387^{*}$ & .177 & $-.479^{* *}$ & $.787^{* *}$ & .148 & -.167 \\
\hline Cob diameter & & 1 & $.869^{* *}$ & $.844^{* *}$ & $.421^{*}$ & .240 & $-.512^{* *}$ & $.735^{* *}$ & .168 & -.203 \\
\hline No.of grain cob $^{-1}$ & & & 1 & $.907^{* *}$ & $.397^{*}$ & .297 & $-.643^{* *}$ & $.843^{* *}$ & .311 & $-.353^{*}$ \\
\hline Grain wt. cob $^{-1}$ & & & & 1 & $.584^{* *}$ & $.485^{* *}$ & $-.703^{* *}$ & $.879^{* *}$ & $.401^{*}$ & $-.532^{* *}$ \\
\hline 100 grain wt. & & & & & 1 & $.588^{* *}$ & $-.696^{* *}$ & $.611^{* *}$ & $.645^{* *}$ & $-.687^{* *}$ \\
\hline Grain yield & & & & & & 1 & $-.654^{* *}$ & .322 & $.723^{* *}$ & $-.753^{* *}$ \\
\hline Fodder yield & & & & & & & 1 & $-.799^{* *}$ & $-.866^{* *}$ & $.773^{* *}$ \\
\hline Total dry matter & & & & & & & & 1 & $.581^{* *}$ & $-.495^{* *}$ \\
\hline Leaf area index & & & & & & & & & 1 & $-.702^{* *}$ \\
\hline Light & & & & & & & & & & \\
\hline transmission & & & & & & & & & & 1 \\
\hline ratio & & & & & & & & & & \\
\hline
\end{tabular}

*indicates significant at $5 \%$ level ;**indicates significant at $1 \%$ level

\section{Economic analysis}

The highest gross return and benefit cost ratio (BCR) was obtained from the treatment having 1,11,111 plants ha ${ }^{-1}$ with no clipping (Tk. $98819 \mathrm{ha}^{-1}$, BCR 1.78) while the lowest from the treatment with removal of all leaf blades except those adjacent to cob in 66,667 plants ha ${ }^{-1}$ (Tk. 63604 ha $^{-1}$, BCR 1.22) (Table 3). In case of dual purpose,1,11,111 plants $\mathrm{ha}^{-1}$ with removal of tassel and all leaf blades below the lowermost cob gave the highest gross return (Tk. $89520 \mathrm{ha}^{-1}$ ) but 66667 plants ha ${ }^{-1}$ with removal of all leaf blades below the lowermost cob gave the highest BCR (1.6).

Table 3. Yield and return of maize var.BARI hybridmaize-7 production in three population densities grown under four different clipping levels

\begin{tabular}{clllllll}
\hline $\begin{array}{c}\text { Treatment } \\
\text { combination }\end{array}$ & $\begin{array}{l}\text { Cost } \\
(\mathrm{Tk} .)\end{array}$ & $\begin{array}{l}\text { Fodder } \\
\text { yield } \\
\left(\mathrm{t} \mathrm{ha}^{-1}\right)\end{array}$ & $\begin{array}{l}\text { Grain } \\
\text { yield } \\
\left(\mathrm{t} \mathrm{ha}^{-1}\right)\end{array}$ & $\begin{array}{l}\text { Return } \\
\text { from } \\
\text { fodder } \\
\left(\text { Tk* }^{*}\right)\end{array}$ & $\begin{array}{l}\text { Return from } \\
\text { grain (Tk.) }\end{array}$ & $\begin{array}{l}\text { Gross } \\
\text { return } \\
(\mathrm{Tk} .)\end{array}$ & BCR \\
\hline $\mathrm{D}_{1} \mathrm{C}_{1}$ & 50387 & 0.00 & 6.57 & 0.00 & 82147 & 82147 & 1.63 \\
$\mathrm{D}_{1} \mathrm{C}_{2}$ & 51657 & 1.905 & 6.23 & 4763 & 77894 & 82657 & 1.6 \\
$\mathrm{D}_{1} \mathrm{C}_{3}$ & 52005 & 1.905 & 5.93 & 4763 & 74086 & 78849 & 1.52 \\
$\mathrm{D}_{1} \mathrm{C}_{4}$ & 52145 & 4.250 & 4.24 & 10627 & 52978 & 63605 & 1.22 \\
\hline $\mathrm{D}_{2} \mathrm{C}_{1}$ & 52434 & 0.00 & 6.49 & 0.00 & 81080 & 81080 & 1.55 \\
$\mathrm{D}_{2} \mathrm{C}_{2}$ & 53755 & 2.397 & 6.15 & 5992 & 76862 & 82854 & 1.54
\end{tabular}


Emran et al.

\begin{tabular}{rlllllll}
$\mathrm{D}_{2} \mathrm{C}_{3}$ & 54342 & 2.397 & 6.32 & 5992 & 79033 & 85025 & 1.56 \\
$\mathrm{D}_{2} \mathrm{C}_{4}$ & 54501 & 4.627 & 4.69 & 11567 & 58686 & 70253 & 1.29 \\
\hline $\mathrm{D}_{3} \mathrm{C}_{1}$ & 55489 & 0.00 & 7.91 & 0.00 & 98820 & 98820 & 1.78 \\
$\mathrm{D}_{3} \mathrm{C}_{2}$ & 56338 & 3.127 & 6.48 & 7817 & 80976 & 88793 & 1.57 \\
$\mathrm{D}_{3} \mathrm{C}_{3}$ & 56867 & 3.127 & 6.54 & 7817 & 81704 & 89521 & 1.57 \\
$\mathrm{D}_{3} \mathrm{C}_{4}$ & 57265 & 6.258 & 5.21 & 15644 & 65080 & 80724 & 1.41 \\
\hline $\mathrm{LSD}(0.05)$ & & & & & 0.9473 & 11840 & 0.2 \\
$\mathrm{CV}(\%)$ & & & & & 9.23 & 8.53 & 7.87 \\
\hline
\end{tabular}

$\mathrm{D}_{1}=(75 \mathrm{~cm} \mathrm{x} 20 \mathrm{~cm}), 66667$ plants ha ${ }^{-1}$

$\mathrm{D}_{2}=(60 \mathrm{~cm} \times 20 \mathrm{~cm}), 83333$ plants ha ${ }^{-1}$

$\mathrm{D}_{3}=(60 \mathrm{~cm} \times 15 \mathrm{~cm}), 111111$ plants ha ${ }^{-1}$

$\mathrm{C}_{4}=$ Removal of all leaf blades except those adjacent to cob

$\mathrm{C}_{1}=$ Control (No clipping was done)

$\mathrm{C}_{2}=$ Removal of all leaf blades below the lowermost cob

$\mathrm{C}_{3}=$ Removal of tassel and all leaf blades below the lowermost cob

*75Tk = 1 USD (approximately)

\section{Conclusion}

Grain yield increased up to $20 \%$ if no clipping was done with 1,11,111 plants ha ${ }^{-1}$, however, with the same density and removal of all leaf blades produced the highest fodder yield. The highest grain yield loss (35.5 \%) was observed in 66,667 plants ha $^{-1}$ with removal of all leaf blades, except those adjacent to cob. The highest gross return and BCR was obtained from 1,11,111 plants ha ${ }^{-1}$ with no clipping (Tk. $98820 \mathrm{ha}^{-1}$ and 1.78) and the lowest from 66667 plants $^{-1} \mathrm{w}^{-1}$ with removal of all leaf blades except those are adjacent to cob (Tk. $63605 \mathrm{ha}^{-1}$ and 1.22). In case of both grain and fodder yield, the combination of 1,11,111 plants ha ${ }^{-1}$ with removal of tassel and all leaf blades below the lowermost cob gave the highest gross return (Tk. $89521 \mathrm{ha}^{-1}$ ) but 66,667 plants ha ${ }^{-1}$ with removal of all leaf blades below the lowermost cob gave the highest BCR (1.6).

\section{References}

Ahmad, N. and F. C. Muhammad. 1999. Plant density effect on yield and quality of maize seed. J. Agric. Res. 37 (1): 25-29.

Barthakur, B. C., S. Nath and P. K. Purkayastha. 1975. Effect of dates of sowing, rates of nitrogen and planting densities on grain yield of hybrid maize Ganga 11. Indian J. Agron. 20(3): 257-259.

Burton, W. J. 2004. Effects of defoliation on seed protein concentration in normal and high protein lines of soybean. Crop Sci. 72: 131- 139.

Chaudhary, A. N., M. I. Latif, Haroon, M. Ur-Rasheed and G. Jilani. 2005, Profitability increase in maize production through fertilizer management and defoliation under rain fed cropping. Int. J. of Bio.and Biotech., 2(4): 1007-1012.

Desiderio, E., L. Cuocolo, G. Mariani and M. Monotti. 1989. Effects of sowing date and plant density on yields of maize of different maturity groups. (In Italian). Informatore-Agrario. 45(14): 57-69.

Egile, D. B. 2000. Variation in leaf starch and sink limitations during seed filling in soybean. Crop Sci. 39: 1361-1368.

Hassen, H. 2003. Effect of defoliation on yield components of maize and under sown forage. Agri. Topica, 18(1/2): 5-7. 
Sourch-Sink Manipulation and Population Density of Hybrid Maize

Hsu, A. N. and S.C. Huang. 1984. Effects of plant density on yield and agronomic characteristics of maize in spring and autumn cropping seasons. Bull. Taichung District Agril. Improv. Sta. Pub. No. 9. pp.13-21.

Kolcar, F. and Z. Videnovic. 1988. Effect of time of planting and plant density on the grain yield of some ZP hybrid of maize FAO maturity group 200. Arhiv-Za-Poljopri-vredne-nauke (Yugoslavia) 49 (176): 309-320.

Li-Xiangjun, S. AnpingInanaga, A. E. Enejj and A. M. Ali. 2005. Mechanisms promoting recovery from defoliation in determinate and indeterminate soybean cultivar. J. Food Agric. Env.3(3/4):178-183.

Loesch, P. J. J., C.F. Stark and M. S. Zuber. 1976. Effects of plant density on the quality of cobs used for corn cob pipes. Crop Sci. 16(5): 706-709.

Madhavan, M. V., S. Shanmuegasundaram and S. P. Palaniappar. 1986. Effect of population on physiological growth parameters of pigeon pea genotypes in sole and inter cropped stand with sorghum co. 22. J. Agron. Crop Sci. 157(1): 43-61.

Mostert, A. J. and J. N. Marais. 1982. The effect of detasselling on the yield of irrigated maize. Crop Prod. 11: 163-167.

Mrityunjoy, B., I. M. Ahmed, M. Asaduzzaman and W. Sultana. 2008. Performance of intercropping grain maize with triticale and grasspea as forage crops. Intl. J. Sustain. Crop Prod. 3(6): 34-37.

Narayanaswamy, M. R., V. Veerabadran, C. Joyanthi and C. Chinnuswammy. 1994. Plant density and nutrient management for rainfed maize in red soil. Madras Agril. J. 81(5): 248-251.

Osorio, F.O. 1976. Population effects on yield and other characteristics of maize in the E-1 Zamorano Valley, Honduras. Field Crop Abst. 33(2): 126-1980.

Rathore, D. M., K. Singh and B. P. Singh. 1976. Effect of nitrogen and plant population on the yield attributes of maize. Indian J. Agric. Res. 10(2): 79-82.

Sabir, M. R., S. A. H. Shah, M. A. Shahzad and I. Ahmed. 2001. Effect of plant population on yield and yield components of maize. J. Agric. Res. 39(2): 125-129.

Sawhney, J. S., S. S. Bhinder, M. S. Sidhu and R. S. Narang. 1989. Agronomic practices for higher productivity in winter maize. Indian J. Agron. 34(1): 24-26.

Simenov, N. and G. Tsankova. 1990. Effect of fertilizers and plant density on yield of maize hybrids with two years. (In Bularian). Rasteniev'dni-Nauki 27(8): 14-18.

Sufian, M. A. and M. Z. Abedin. 1985. Effect of plant population and plants per hill on the growth and yield of sweet corn. Bangladesh J. Agri. 10(2): 17-22.

Tano, F., M. R. Mannino and F. Aiello. 1987. Row spacing and plant density of grain maize (Part Two). (In Italian). Informatore-Agrario. 43(26): 59-61.

Vasic, G., Krzic. and D. Budimirovic. 1988. Effect of late planting on maize yield under irrigation. SavremenaPoljoprivreda (Yugoslavia) 36(11-12): 506-516.

Vivas, H., R. Moresco and S. Gambaudo. 1988. Effects of nitrogen and plant density on maize production in eastern Argentina. Turrialba 38(2): 127-131.

Wang, O. Q. 1996. Effects of altered source sink ratio on canopy photosynthetic rate and yield of maize. Photosynthetica. 32: 271-267.

WIPO. 2006. Improved grain quality through altered expression of seed proteins. Pub. No.: WO/2006/071219. http://www.wipo.int/pctdb/en/

Zelitch, I. 1982. The close relation between net photosynthesis and crop yield. Bio-Sci. 32: 796-802.

Zewdu, T. 2003. Effect of defoliation and intercropping with forage legumes on maize yield and forage production. Trop. Sci. 43(4): 204-207. 
Emran et al. 